\title{
Learning from experience: defence disposals in the UK contrasted with sustainable redevelopment in four US east coast navy yards
}

\author{
C. M. Clark \\ Wessex Institute of Technology, UK
}

\begin{abstract}
Modern war is now conducted remotely - via unmanned military drones, robots and chemical weapons; troops can be moved into battle rapidly from advanced positions. These developments in attack and defence technology render many facilities in fixed positions - navy bases, garrisons, forts, airbases, training grounds - increasingly redundant.

Many governments are disposing of these surplus defence sites, some of them historic, but the processes and the outcomes vary enormously from country to country. In the UK large swathes of defence land are earmarked for sale in the near future; the Ministry of Defence is under increasing pressure to rationalise its holdings and save public money. The United States Government is considering selling off many more of its publicly owned assets in the face of prolonged recession.

Although the closure of military sites is happening all over the world, transfers of learning from the accumulating experience of post-defence reconstruction, both within and between countries has at best been sporadic. This conference is one of the first to examine the complex and particular challenges to land reuse thrown up by reductions in defence budgets. Planned disposals offer a unique opportunity to provide long-term benefits to local communities whose economies are affected by losses of defence related employment, but they do not always result in such outcomes. Examples of good practice in this paper are drawn from post defence experience in navy bases on the east coast of America, complementing the paper on Brooklyn Navy Yard. It is apposite to examine how former defence sites are faring in different countries in terms of land use and financial viability, and what local communities are
\end{abstract}


gaining from renewed and civilian activity on these sites, once so important to national defence.

Keywords: defence disposals, navy yards, governance, innovation.

\section{Disposals of defence sites}

While China, Brazil and developing countries are increasing their spending on defence, many western countries are scaling down their war budgets. Two examples of reduction are the United States and the United Kingdom. The United States Government is considering selling off many more of its publicly owned assets in the face of prolonged recession [1]. Sales of 350 closed military installations have produced $\$ 1.5$ billion over the last 20 years, according to the Congressional Budget Office. The British Ministry of Defence which owns nearly $1 \%$ of the UK's landmass, much of it already or soon to be surplus to requirements, has raised a total of $£ 3.4 \mathrm{bn}$ from land sales between 1998/99 and 2008/09 which gives some indication of the scale of this process [2].

The wide spectrum of disposal methods in different countries - from sale to the highest bidder (the UK and Germany) to free transfer for community needs such as homelessness or education (the US), results in widely differing new land uses and economic, environmental and social outcomes. As defence ministries seek to rationalise their landholdings, the opportunity to achieve public benefits and sustainable long-term economic reconstruction for local communities is enabled or lost according to the aims of such disposal systems and to the economic climate in which these transfers to civilian uses are taking place.

Until 2007/8 in the UK with a rising tide of land values and property prices, developers have had the money to fund community infrastructure, such as affordable housing at Caterham Barracks, to preserve historic buildings at Royal William Yard in Plymouth, Woolwich Arsenal and the Vulcan building and Customs House in Portsmouth Gunwharf. Central government funding for new infrastructure such as transport and renewed services was also available. Since the onset of recession in 2008, however, public gains from redevelopment of defence sites are much harder to realise, both for the MOD and for local communities. The government's deficit reduction strategy has spurred public bodies in the UK into reassessment of their requirements for land and buildings, creating a glut of unwanted and sometimes important historic property [3].

Many public benefits are unlikely to be realised while the UK Treasury requires government departments to obtain maximum market value within a short timescale. They are set targets for asset sales to help to balance their departmental budgets, and if these are not met, savings must be found elsewhere. Public benefit is thus defined in the Ministry of Defence by price, not by quality and benefit to the local community - yet these are key objectives for other government agencies and local governments [4].

Despite this enormous transfer of defence sites to civilian uses, which is happening in so many parts of the world, as Dobson says, there has been no overarching academic research in the UK into the best way of achieving public benefit from these disposals, and the issue is not high on the policy agenda. This 
is a cause for concern, as there is a risk that mistakes will be repeated through a lack of awareness of good practice and a desire by central government to maximise the short-term gain to the Exchequer It is worth examining whether approaches adopted in other countries, where land is transferred to another public sector or community organisation at a reduced or nominal price, paying particular attention to the public accounting mechanisms and the costs and benefits to the public purse may achieve more lasting benefits [3].

\section{Examples of good practice on the east coast of America}

This paper examines four naval bases in various stages of redevelopment - from Washington Navy Yard which is very much in operational use, though outer areas have already been disposed of and are being redeveloped; Philadelphia Navy Yard, home to a mothballed fleet and commercial ship repair which is being developed as a green business, education and research campus; Charlestown Navy Yard in Boston which is split between heritage uses managed by the National Park Service and commercial and residential reuse by the Boston Redevelopment Authority; and Brooklyn Navy Yard which has had nearly fifty years of redevelopment and renewal, focussed on job creation and education, which opened its first visitor attraction on Veterans' Day, November 112011. Taken together, their experience offers inspiring lessons for redundant naval facilities in other parts of the world. Romano and Kimball's paper sets out developments in Brooklyn Navy Yard.

These yards' location, their release date, the local involvement in the new governance structures which took them on to find and fund appropriate new civilian uses, the tax breaks and grants they are eligible for and the long timescale are all factors in their differing futures.

\section{Washington DC Navy Yard}

As befits its position in the capital, Washington Navy Yard houses important administration functions for the navy, as well as some of the oldest standing buildings in Washington. The oldest shore establishment of the US Navy, it was established in 1799. It was built under the direction of Benjamin Stoddert, the first Secretary of the Navy, under the supervision of the first commandant, Commodore Thomas Tingey. The north wall and guardhouse now known as the Latrobe Gate were built in 1809.

During the War of 1812, the Navy Yard was a support facility and a vital strategic link in the defence of the capital city. Sailors and marines were part of the hastily-assembled American army. As the British marched into Washington, holding it became impossible. Tingey, seeing the smoke from the burning Capitol, ordered the Yard burned to prevent its capture by the enemy. Tingey's own quarters and the Latrobe Gate were spared from the flames. After 1812 Washington Navy Yard never regained its prominence as a shipbuilding facility. The Anacostia River was too shallow to accommodate larger vessels, and the Yard was too inaccessible to the open sea. It then specialised in ordnance and 
technology. One of the earliest steam engines in the U S was used to manufacture anchors, chain, and steam engines for warships.

At its peak, the Yard consisted of 188 buildings on 126 acres $\left(0.5 \mathrm{~km}^{2}\right)$ of land and employed nearly 25,000 people. Small components for optical systems, and enormous 16-inch $(410 \mathrm{~mm})$ battleship guns were all manufactured there. In December 1945, the Yard was renamed the U.S. Naval Gun Factory. Ordnance work continued for some years after World War II until it was finally phased out in 1961. In 1964 it was redesignated the Washington Navy Yard. The deserted factory buildings began to be converted to office use. The yard was added to the National Register of Historic Places in 1973, and designated a National Historic Landmark in 1976 [5]. The historic officers' houses and monumental Latrobe Gate also enjoy legal protection.

The river Anacostia has silted up, so no waterfront activity takes place there now, apart from the preserved destroyer USS Barry which is accessible across a bridge over the new waterfront foot and cycle path along the river. Several important historic buildings and industrial structures survive in the densely built up site. The National Naval Museum is housed in a huge workshop, and the Naval Art Gallery's stores are in the oldest building of 1800 . Technical drawings and plans of the yard and images from very recent conflicts make the gallery as well as the museum worth a visit. The pioneer Experimental Model Basin 1898-1955 founded by Rear Admiral David Watson Taylor, Director until 1915, consisted of a 470-foot towing tank and $8 \times 8$ foot closed circuit wind tunnel 1914. It is being converted into a Cold War display. The site of one of the covered slips - 'ship halls' in US parlance, with its winch house and gearing is visible, the machinery protected in what is now a coffee shop.

Many former machine shops and the forge have been converted into offices, and new offices have also been constructed. The chapel is housed in a small building which was once part of a power station. The downriver portion of the yard has been disposed of, including a large power station, metal framed workshop, massive storage buildings and a basin, as well as large areas now cleared of buildings. A new park is being created along the river and around the basin. The workshop is being converted into retail units and restaurants and a temporary building houses the Trapeze School. Next downriver, the massive and impressive Army College awaits new uses. The area and the large new government department of Transport building which has interpretation panels on the history of transport on the walls and pavement are all served by a Navy Yard metro station, making access to other parts of the city easy.

\section{Philadelphia Navy Yard}

Philadelphia Navy Yard, at 1,200 acres the largest of these examples, was disposed of to the Navy Yard Development Corporation, which commissioned a master plan published in 2004 [6] as a guide to future land uses in its pleasant open campus. My informants on my October 2011 visit were Mark Seltzer, Director of Navy Yard Management and Development at PIDC and Brian Berson of Liberty Property Trust, the preferred developer of the site. 
Philadelphia was the cradle of the early American industrial revolution. It was not only the first city in the States to supply fresh water as a municipal responsibility, but the genesis of the American navy. Under the direction of Benjamin Franklin ships from Philadelphia's local naval establishment were sold to Congress in 1775 to form a Continental navy. In 1801 a US Navy Yard was established in Southwark Philadelphia, building timber and later iron steampowered warships. In 1863 after a fire, a new yard was developed from 1874 at League Island, two miles down river, laid out in a generous street grid which still survives in the green campus of the Yard today. The Bureau of Yards and Docks Storehouse and Office (Building 1), Boiler and Engine House (2), Iron Plating Shop (3), Bureau of Steam Engineering Storehouse and Shop (4) and Bureau of Construction and Repair Mold Loft building (7) were built between 1874 and 1877. The Marine Corps Reservation barracks and Training School were transferred from Newport Rhode Island. During WWI expansion a naval aircraft factory found the river ideal for testing seaplanes. In 1919 a 1,000 foot drydock made the Yard American's most modern facility for large ship construction. It reached its height in WWII when the workforce reached nearly 60,000. Two of the largest government dry docks, numerous heavy machine and industrial shops, research and development laboratories for turbine engines, builder propellers, aircraft, rockets and submarines were added. After the Vietnam war the US fleet shrank from 600 to 300 ships, outnumbered by the Soviet navy. Closure loomed and in 1977 the Mayor of Philadelphia formed a Commission of Defense Conversion which with the Philadelphia Industrial Development Corporation led to the creation of a Community Reuse Plan submitted to the navy in 1994 as a basis for transition and a conveyance for redevelopment [6].

As in the case of Washington DC, good transport connections to the city are vital to the future of former navy yards. The Philadelphia yard is located down river of the city centre three quarters of a mile from the end of the subway line which serves a new stadium and sports facilities, with a connecting shuttle bus for those working in and visiting the yard. An important highway skirts the site, and there is also an extensive railway yard which now brings in supplies to the new users such as the TastyKake factory, a Philadelphia institution on the site of a naval prison.

The yard is home to a mothballed fleet including two giant aircraft carriers moored in the Delaware, a spectacular backdrop to the new civilian activity in the many impressive brick and metal framed workshops and more modern concrete buildings. Naval and civilian ship repair continues in the downriver part of the site, the only area not openly accessible. The navy's still here - not only in obsolete ships but also in cutting edge research - on fuel cells and communication engineering. "I make buildings talk to each other" said one engineer waiting at a bus stop. The emphasis of the whole yard is on sustainability - whether it is adaptive reuse of the many barrack and workshop buildings, or newbuild for new activities. A cluster of biomedical and physical engineering firms is driving commercial developments in the Yard. The Navy Yard Keystone Innovation Zone which attracts special tax breaks is the driver for research and development partnerships with universities and the navy. There are 
now over 70 companies, 7,000 employees and five million square feet of development on site.

The Philadelphia Navy Yard Development Corporation sets a first class example in its conversion of a barrack block whose narrow form with many windows was ideally suited to office conversion. The building's mechanical systems have been upgraded to the highest specification. The Greater Philadelphia Innovation Cluster for Energy-Efficient Buildings is a consortium of academic institutions, federal laboratories, global industries, regional economic agencies and other stakeholders that joined forces to secure $\$ 130 \mathrm{~m}$ in federal grants to establish an Energy Innovation Hub. Its aim is to foster national energy independence and create quality jobs for the region. As a demonstration project, Building 661 will undergo a full-spectrum retrofit [7].

Hands on technical training is also offered on site. The Workshop School, an alternative high school experience launched in autumn 2011. In the late 1990s The Hybrid X team, a science-driven after school programme, attracted national fame for building electric and bio-diesel cars that outperformed college teams. The Workshop School expands that opportunity to a full school day for pupils from three local high schools. It is housed in the Civil Engineer's Residence of 1880 overlooking the hulking ships mothballed in the Yard, funded in part by a grant from the Greater Philadelphia Innovation Cluster [8]. The Portsmouth Naval Base Property Trust plans a similar full time technical school.

Newbuilds too - for firms such as GlaxoSmithKline are also moving from high rent central Philadelphia to highly sustainable high tech new offices which reach the highest standards of sustainable design. The building represents a $\$ 100$ million investment by the private sector [9].

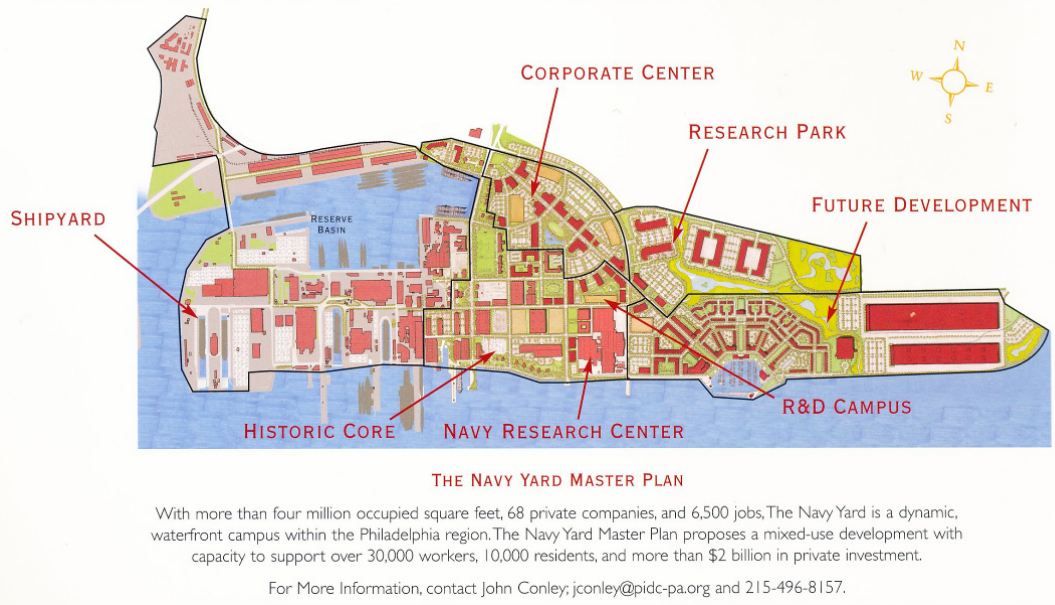

Figure 1: $\quad$ Philadelphia navy yard master plan 2008.

Fashion design and manufacture are replacing heavy engineering. Urban Outfitters, has moved its entire operation including manufacturing from central 
Philadelphia to the navy yard, occupying seven handsome large brick and steel framed workshops. The most impressive - and only publicly accessible building is a huge lightfilled machine shop now used as their major recreation space. Building 342 was going to be a major cultural centre - but now it's now Urban Outfitters' social and cultural hub. The building's lit by regular rooflights much like Boathouse 4 in Portsmouth dockyard. It has huge end windows, and it's at least as long as Portsmouth's Factory of 1900. Giant bamboos reach to the dramatic glazed roof, a café and seating area has the world's design magazines, a Buddha statue and waterfall reigns serenely over a pond filled with carp, an enclosed power plant is topped by a gym, peripheral work stations and a yarn store, and there is an informal art gallery on the wall of another building within the machine hall's huge envelope. Comfortable seating in Dayglo colours dramatises the space - great for chilling out or an informal work discussion. Small groups showed each other clothing samples. In the evening there was a free concert by the Philadelphia Philaharmonic, starting with Vultava - perhaps in honour of the mighty Delaware river - one and a half miles wide at this point. The Delaware's confluence with the Schuylkill River forms the seaward boundary of the navy yard.

What was so strange to English perception was the openness of the site, and the complete absence of any physical demarcation of what was civilian and what navy - no guards with machine guns here - and as long as you don't try to enter the Yard at the weekend - very little of the area is off limits. The year before, we were brusquely turned away from entering the Yard on a Saturday, when my we tried to enter. Only the active shipbuilding and naval areas downriver to the southwest are fenced. As the TastyKake guide said: "Terrorists: come on weekdays!"

Next to Urban Outfitters' recreation building and its other workshops is a flooded drydock, its edges planted with water loving plants. As a waterfront city, Philadelphia is responding to rising sea levels which surge up the Delaware River and into coastal communities, and to increased and concentrated rain which floods the land and flows through streams and flood plans toward the Delaware. The possibility of 100 year floods has led to recommendations that the coastal zone should be managed as a dynamic, changing landscape by opting for more self-sustaining solutions, by retreating from dams, dykes, levees and sea walls, allowing the sea to reclaim them as estuarine habitats [10]. Soft engineering such as this flooded dry dock is an example. The Navy Yard masterplan of 2004 talks of demolishing sea walls; there have been recent high tides which have overtopped them.

New phases of the implantation of the Master Plan include extension of the metro line from central Philadelphia into the yard with a return loop. What is distinctive about this reinvention is the close and productive collaboration between the publicly owned Development Corporation and the favoured commercial partner, a partnership which is creative in financial and well as technical design expertise.

Residential development - often the favoured land use in the UK - in response to the high prices UK developers pay - has been resisted in 
Philadelphia and Brooklyn; it is only one of the mixed uses evident in Boston too. New jobs - some in new industries - are a greater priority - to repair the losses of naval and support industries to the local economy.

\section{Brooklyn Navy Yard}

"New York City real estate is a canvas that is never quite finished - its landscape and skyline are constantly been redrawn." [11]. Since the US Navy left in 1966, Brooklyn Navy Yard has been 45 years in the remaking. As Daniella Romano's paper describes, the federal government decommissioned the nation's foremost naval shipbuilding facility in 1966, a devastating blow to Brooklyn's economy. The long-term effort to develop the Yard for diversified industrial use has blossomed into a recognizable asset for the City, and anchored Brooklyn's manufacturing in traditional and innovative new industries. Practical lessons learned from this complex base realignment process serve broadly as a model for urban areas that need to reinvent themselves - which might one day include Portsmouth England - when they are ready to embrace a new industrial economy.

\section{Charlestown Navy Yard Boston}

One of the six original naval shipyards in the United States, 35 acres for the Charlestown Navy Yard was purchased in 1800 and the yard was established shortly after. Over time, the area was extended by landfill to 83 acres. The first U.S. ship of the line, USS Independence was built there. The British landing place for the Battle of Bunker Hill in 1775 is marked with a plaque. In the 1830s a tidal flat was filled in behind a new seaway and two covered slips and a large ship hall were built. In 1833 the United States frigate Constitution was constructed in the first naval drydock in New England, designed by prominent civil engineer Loammi Baldwin Jr. "Timber sheds, a mast house, ropewalk, sail lofts and wharves crowded the yard. Steam, and later electricity, further transformed the yard. Machine shops, a forge and foundries now served a navy made of steel. Hemmed in by river and town, the yard pushed into the harbor with piers, railways and cranes" [12].

In 1975 the historic ship floated out of the dock-the last commissioned vessel to use the facility. The impressive granite Ropewalk supplied cordage for the Navy from the time it opened in 1837 until the Yard closed in 1974. It was primarily a repair and storage facility until the 1890 s, when it started to build steel ships for the "New Navy". The Yard was widely known for its leadership in technical innovation. In the early 20th century, a second drydock was added. During WWII, it repaired damaged British ships and built Liberty ships and Captain class frigates as Lend-Lease for the Royal Navy. World War II ships were modified for Cold War service [13]. After WWII an Essex-class carrier and 18 escort carriers were mothballed at the South Boston Annex of Boston Naval Shipyard. The decommissioning of hundreds of warships created similar scenes in navy yards along American coasts. 
The Yard closed after the Vietnam War. When ideas for redevelopment were being discussed, one proposal was to convert it into a construction yard for oil tankers. This would presumably have meant loss of most of the historic buildings. The Yard had, however, already been designated a Registered National Historic Landmark by the Department of the Interior in 1966. Instead, Congress established Boston National Historical Park, which includes 30 acres of the historic Charlestown Navy Yard, which was transferred to the National Park Service. Its mission is "to interpret the art and history of naval shipbuilding." Part of the yard remains in operation to support the USS Constitution. The USS Cassin Young 793, a destroyer of 1943 which is open to the public, is in the fully commissioned Drydock No. 1. This is still used for ship maintenance, mostly on historic vessels. The Commandant's House on a hill overlooking the yard may be hired for weddings and corporate events, which unfortunately precludes general public access. The USS Constitution Museum and history of the shipyard is housed in an elegant and sober limestone dockyard building, reminiscent of Plymouth dockyard.

New transport links here - as in other yards - are vital. Charlestown Yard is near the north end of the Freedom Trail and is seen by thousands every year. The MBTA Water Shuttle linking to the city centre stops at nearby Pier 3, provides easy visitor access to the Yard

After sitting dormant for many years, the remaining 100 acres are being redeveloped in mixed use: medical research, offices, a hotel: the Constitution Inn, new blocks of flats and houses, a public park and a yacht marina. The sites of the covered slips - 210 feet long and six storeys high - are marked out with granite blocks. Drydock 5 of WWII has been filled in. High quality granite paving and avenues of mature trees enhance the serious and purposeful atmosphere of the new life of the Yard.

An impressive 1950s multi-storey storage facility, Building 149, now houses a large medical research institute linked to Massachusetts General Hospital. A Cyclotron \& Nuclear Pharmacy, Harvard University Employees Credit Union, autism research and a Center for Biomedical Imaging all occupy space within it. The canteen, like all this part of the Yard, is open to the public.

The historic Captain's Quarters at the end of the site now house the Inland Underwriters Agency, the office for International Special Risk and the Massachusetts General Hospital Children's Center. The end of the yard is almost overhung by a gigantic bridge. On site interpretation by National Park Service is excellent throughout. Right at the end of the site Building 114, the navy's Spar Shed and Sawmill was constructed in 1900 on the site of the original masthouse and spar shed which was burnt down. It was primarily used for boatbuilding until the closure and has now been converted to an office and conference centre. It is not open to the public, but a public right of way through it allows access to the river and a small park, with the huge bandsaw reinstalled outside. Right at the end of the site, the Navy Yard has a new neighbour: the huge Spaulding Rehabilitation Hospital is being built there.

Not all the historic dockyard buildings outside the National Historic Park area have found new uses. The Steam Engineering Building No. 42 survives as a 
skeleton. An impressive octagonal building is currently offered for lease, and the impressive granite ropewalk along the landward boundary of the site has been unused for many years.

The most desirable and valuable part of the nary yard, the waterfront, has been redeveloped with modern residential development, yachting facilities, a marina, the Seaport Academy and open areas - mostly with open access. A large unused area extends to the harbour in front of the largest new residential block.

\section{Conclusion}

These four American yards have found new life in very different ways. Philadelphia and Brooklyn, directed by locally controlled development corporations, continue dockyards' tradition of technological innovation - into green industry and medical and communications research - via the creation of high skill new jobs and enterprises. Creative public/private partnerships and financing have made this development possible. Federal, regional and local investment funds new infrastructure, successfully attracting substantial private investment. Residential development, the most lucrative land use in the UK favoured by developers who pay high prices for defence sites, was specifically excluded in three of these yards and in Governor's Island New York. The long timescale of redevelopment has enabled uses to evolve and managements to respond to new ideas. The innovation and enterprise demonstrated in these impressive examples of reuse have much to teach - particularly to countries such as the UK where naval strength continues to diminish and dockyards are under threat of closure.

\section{References}

[1] New York Times Business 30 September 2011 p. B2

[2] National Audit Office 2010 Ministry of Defence $A$ defence estate of the right size to meet operational needs London The Stationery Office.

[3] Julian Dobson January 2012 Forces for Good Making the most of military land for public benefit The Bill Sargent Trust Research for Action.

[4] Julian Dobson In the Public Interest? Community Benefits from Ministry of Defence Land Disposals Research Report The Bill Sargent Trust Research for Action 2010.

[5] http://en.wikipedia.org/wiki/Washington Navy Yard; Charlestown Navy Yard Barbara A Bither and Boston National Historical Park Arcadia Publishing 1999; The Washington Navy Yard An Illustrated History Edward J Marolda Naval Historical Center Washington 1999.

[6] 2004 Philadelphia Navy Yard Master Plan Philadelphia Industrial Development Corporation, Liberty Property Trust, Synterra Partners, Robert AM Stern Architects Philadelphia.

[7] Research \& Development Philadelphia Industrial Development Corporation Philadelphia; http:gpichub.org 
[8] http://technicallyphilly.com/2011/11/07/workshop-school-experimentalproject

[9] The Navy Yard News Summer 2011 The Navy Yard Philadelphia

[10] Estuary News Newsletter of the Partnership for the Delaware Estuary Volume 21 Issue 2 Winter 2011.

[11] Vivian S. Toy ‘Is that a bulldozer I hear?’ New York Times October 92011 Real Estate P.1

[12] Onsite interpretation

[13] http://en.wikipedia.org/wiki/Boston Navy Yard 